Vol. 8 (1999): 239-252.

\title{
Use of rapeseed and pea grain protein supplements for organic milk production
}

\author{
Hannele Khalili \\ Agricultural Research Centre of Finland, Animal Production Research, FIN-31600 Jokioinen, \\ Finland, e-mail: hannele.khalili@mtt.fi \\ Eeva Kuusela \\ University of Joensuu, Department of Biology, PO Box 111, FIN-80101 Joensuu, Finland \\ Eeva Saarisalo \\ Agricultural Research Centre of Finland, Animal Production Research, FIN-31600 Jokioinen, Finland \\ Marjatta Suvitie \\ Agricultural Research Centre of Finland, North Savo Research Station, FIN-71750 Maaninka, Finland
}

\begin{abstract}
Grass-red clover silage was fed ad libitum. In experiment 1 a duplicated 4 x 4 Latin square design was used. A mixture of oats and barley was given at $8 \mathrm{~kg}(\mathrm{C})$. Three isonitrogenous protein supplements were a commercial rapeseed meal $\left(218 \mathrm{~g} \mathrm{~kg}^{-1}\right.$ dry matter (DM); RSM), crushed organic field pea (Pisum sativum L.) (452 $\mathrm{g} \mathrm{kg}^{-1} \mathrm{DM}$; P) and a mixture of pea (321 $\left.\mathrm{g} \mathrm{kg}^{-1} \mathrm{DM}\right)$ and organic rapeseed (Spring turnip rape, Brassica rapa L. oleifera subv. annua) (155 $\mathrm{g} \mathrm{kg}^{-1} \mathrm{DM}$; PRS). Cows on P and PRS diets produced as much milk as cows on the RSM diet. Milk yield was higher but protein content lower with PRS diet than with diet P. In experiment 2 a triplicated $3 \times 3$ Latin square design was used. A mixture of oats $\left(395 \mathrm{~g} \mathrm{~kg}^{-1}\right)$, barley $\left(395 \mathrm{~g} \mathrm{~kg}^{-1}\right)$ and a commercial heat-moisture treated rapeseed cake $\left(210 \mathrm{~g} \mathrm{~kg}^{-}\right.$ $\left.{ }^{1}\right)$ was given at $8 \mathrm{~kg}$ (RSC). The second diet (ORSC) consisted $\left(\mathrm{g} \mathrm{kg}^{-1}\right)$ of oats (375), barley (375) and cold-pressed organic rapeseed cake (250). The third diet (RSCO) consisted ( $\left.\mathrm{g} \mathrm{kg}^{-1}\right)$ of oats (395), barley (395) and commercial heat-moisture treated rapeseed cake (250) and additional rapeseed oil (0.38 kg) to balance fat content between ORSC and RSCO diets. There was no dietary effect on the yield of energy corrected milk. Milk yield was higher with RSCO diet compared with other diets.
\end{abstract}

Key words: field pea, milk composition, organic milk production, protein supplementation, rapeseed, silage intake

\section{Introduction}

Organic dairy farming is increasing in Finland, creating a demand for feed evaluation and for- mulation of diets which can be applied to organic milk production. More information is needed concerning the utilization and relative feeding values of organically cultivated crops in order 


\section{Khalili, H. et al. Protein supplements for organic milk production}

to improve organic dairy cow feeding and feed budgeting. In organic farming systems mineral fertilizers are compensated by recycling of nutrients and nitrogen is supplied through biological nitrogen fixation. Organic farms can attain the same level of productivity as conventional farms, provided that legume-dominated swards account for $3-40 \%$ of the cultivated area and are correctly positioned in the rotation (Granstedt 1992). In organic milk production, cows are fed mainly with home-grown feeds with a high proportion of forage in the diet and a mixture of grass-clover silage is often used as a basal forage in Finland. Feeding red clover-grass silage has increased silage intake (Heikkilä et al. 1992, 1996, Vanhatalo et al. 1995) and duodenal microbial N flow (Vanhatalo et al. 1995) and consequently improved milk production compared with grass silage of similar digestibility. Although red clover-grass silage is a suitable forage for dairy cows, duodenal infusion of casein increased milk yield when cows were given redclover grass silage diet as the sole feed (Khalili et al. 1995a). Protein supplementation has also increased milk production of high yielding dairy cows given grass silage-concentrate diets (Castle 1982, Thomas and Rae 1988, Tuori 1992, Huhtanen 1998).

Field pea is a familiar grain legume in Finnish conventional and a most important grain legume in organic farming systems. In recent decades it has been neglected as a feed for dairy cows. There are only a few results available concerning the effects of pea in milk production. Rapeseed is a valuable crop. Rapeseed meal and cake are the most common protein supplements in Finnish dairy cow diets and have produced considerable production responses (Tuori 1992, Huhtanen 1998). Rapeseed is, however, a newcomer in organic farming systems and it has proved difficult to provide adequate crop protection within the constraints of organic farming. Cold-pressed rapeseed cake, a by-product from rapeseed oil production, is a new protein feed, which has not been evaluated for dairy cow feeding. Native Finnish commercial feeds, such as rapeseed products, are permitted in organic animal production, but their contribution should not exceed $15 \%$.

Two experiments were conducted in order to investigate the effects of conventional or organic protein supplements on milk production. The results here are discussed in relation to the Finnish amino acids absorbed (AAT) - protein balance in the rumen (PBV) system which Tuori et al. (1998) concluded to be the most accurate protein evaluation system for predicting differences in dietary protein value for dairy cows.

\section{Material and methods}

\section{Experimental design, animals and diets}

\section{Experiment 1}

The experiment was conducted on Siikasalmi research farm of University of Joensuu in Liperi with 8 mid-lactating ( $80 \pm 38$ days in milk) Finnish Ayrshire cows, of which four were in their first lactation and the others in their third lactation. Cows were individually fed at 0730 and 1530 and milked at 0600 and 1600 . The experiment was conducted as two balanced $4 \mathrm{x} 4$ Latin squares, each having 21 day periods, comprised of 14 days for dietary adjustment and 7 days for data collection. Cows were divided into two blocks according to parity and within blocks cows were randomly allocated treatments. The four concentrates including $250 \mathrm{~g}$ of a mineral mixture were given at $8 \mathrm{~kg}$ (as fed) and consisted of a mixture (1:1) of oats and barley (control diet) and three isonitrogenous protein supplements of a commercial rapeseed meal (RSM diet), crushed field pea (Pisum sativum L.) (P diet) and a mixture of field pea and crushed rapeseed (Spring turnip rape, Brassica rapa L. oleifera subv. annua) (PRS diet). A commercial mineral mixture contained $\left(\mathrm{g} \mathrm{kg}^{-1}\right) \mathrm{Ca}$ (160), P (64), $\mathrm{Mg}(80)$ and $\mathrm{Na}(90)$ and $20 \mathrm{~g} \mathrm{~d}^{-1}$ of $\mathrm{NaCl}$. Oats, barley, field pea and rapeseed were organically cultivated on Siikasalmi research farm. Organic crop production is based on Council Regulations 
Vol. 8 (1999): 239-252.

(EEC no 2092/91). Pea grain and rapeseed were crushed with a hammer mill to pass through 4 and $2 \mathrm{~mm}$ sieves, respectively. Rapeseed meal was solvent extracted (Raisio Feed Ltd). Composition and calculated feeding values of experimental concentrates are shown in Table 1. Second cut grass-red clover silage was fed ad libitum, and the daily portions were adjusted to provide refusals of 50 to $100 \mathrm{~g} \mathrm{~kg}^{-1}$ of the amount offered. On Siikasalmi research farm, herbage dry matter from a second cut contained on the average $60 \%$ grass (timothy (Phleum pratense) and meadow fescue (Festuca pratensis)) and $40 \%$ clover, mainly as red clover (Trifolium pratense). Herbage was ensiled after wilting ( $6 \mathrm{~h})$ with a formic acid based additive $\left(6 \mathrm{t} \mathrm{t}^{-1}\right)$ into a tower silo.

\section{Experiment 2}

The experiment was conducted on Siikasalmi research farm as three $3 \times 3$ Latin squares, each having 21 day periods comprised of 14 days for dietary adjustment and 7 days for data collection. The experiment was conducted with 9 midlactating ( $79 \pm 40$ days in milk) Finnish Ayrshire cows, of which three were in their first lactation and the others were in their fourth lactation. Cows were divided into blocks according to parity (one block for first lactating) and the remaining 6 cows were divided into two blocks according to milk yield. Within the blocks cows were randomly allocated treatments. Three isonitrogenous concentrates including $250 \mathrm{~g}$ of a mineral mixture were given at $8 \mathrm{~kg}$ (as fed). Experimental concentrates consisted of a mixture of oats and barley supplemented either with commercial rapeseed cake (control RSC diet), coldpressed rapeseed cake (ORSC diet) or a mixture of commercial rapeseed cake and rapeseed oil (RSCO diet) (Table 2). A commercial mineral mixture contained $\left(\mathrm{g} \mathrm{kg}^{-1}\right) \mathrm{Ca}$ (160), P (64), Mg (80) and $\mathrm{Na}(90)$ and $20 \mathrm{~g} \mathrm{~d}^{-1}$ of NaCl. Oats, barley and rapeseed were organically produced as described earlier. On-farm home made rapeseed cake (ORSC) was made from whole rapeseed by pressing oil from the seed with a screw press (Tabypressen 40, Sweden). The fat content of the
Table 1. Composition ( $\mathrm{g} \mathrm{kg}^{-1}$ dry matter (DM)) and calculated feeding values of experimental concentrates (experiment 1).

\begin{tabular}{|c|c|c|c|c|}
\hline & $\mathrm{C}$ & RSM & $\mathrm{P}$ & PRS \\
\hline \multicolumn{5}{|l|}{ Concentrate ( $\left.\mathrm{g} \mathrm{kg}^{-1} \mathrm{DM}\right)$} \\
\hline Oat & 500 & 391 & 274 & 262 \\
\hline Barley & 500 & 391 & 274 & 262 \\
\hline Rapeseed meal $^{1}\left(\mathrm{~g} \mathrm{~kg}^{-1} \mathrm{DM}\right)$ & - & 218 & - & - \\
\hline Field Pea $\left(\mathrm{g} \mathrm{kg}^{-1} \mathrm{DM}\right)$ & - & - & 452 & 321 \\
\hline Rapeseed ( $\left.\mathrm{g} \mathrm{kg}^{-1} \mathrm{DM}\right)$ & - & - & & 155 \\
\hline Crude protein $\left(\mathrm{g} \mathrm{kg}^{-1} \mathrm{DM}\right)$ & 134 & 186 & 184 & 184 \\
\hline $\mathrm{HCl}-\mathrm{fat}\left(\mathrm{g} \mathrm{kg}^{-1} \mathrm{DM}\right)$ & 39 & 44 & 28 & 90 \\
\hline $\mathrm{NDF}^{2}\left(\mathrm{~g} \mathrm{~kg}^{-1} \mathrm{DM}\right)$ & 299 & 282 & 236 & 242 \\
\hline $\operatorname{AAT}^{3}\left(\mathrm{~g} \mathrm{~kg} \mathrm{DM}^{-1}\right)$ & 100 & 112 & 110 & 102 \\
\hline $\mathrm{PBV}^{4}\left(\mathrm{~g} \mathrm{~kg}^{-1} \mathrm{DM}\right)$ & -33 & 6 & -3 & 14 \\
\hline $\mathrm{ME}^{5}\left(\mathrm{MJ} \mathrm{kg} \mathrm{DM}^{-1}\right)$ & 13.0 & 12.6 & 13.3 & 14.1 \\
\hline
\end{tabular}

$\mathrm{C}=\mathrm{a}$ mixture of oat and barley; $\mathrm{RSM}=\mathrm{C}+$ rapeseed meal; $\mathrm{P}=\mathrm{C}+$ pea; $\mathrm{PRS}=\mathrm{C}+$ pea + rapeseed.

${ }^{1}$ solvent extracted.

${ }^{2}$ Neutral detergent fibre.

${ }^{3}$ Amino acids absorbed from the small intestine.

${ }^{4}$ Protein balance value.

${ }^{5}$ Metabolizable energy.

${ }^{3,4,5}$ The values derived from feed tables (Tuori et al. 1995).

remaining rapeseed cake was about half that of whole rapeseed. Commercial rapeseed cake (RSC) was manufactured by removal oil by pressing and a subsequent heat-moisture treatment $\left(\right.$ Öpex ${ }^{R}$, Mildola Ltd). Rapeseed oil was produced by Raisio Feed Ltd. Grass-red clover silage was fed ad libitum as described earlier.

\section{Measurements and analytical procedures}

Milk yields and silage intakes were recorded daily. Silage dry matter (DM) content was determined by oven drying at $105^{\circ} \mathrm{C}$ for $24 \mathrm{~h}$, and DM content was corrected for volatile losses according to Huida et al. (1986). Feed samples were collected on days 15-19 of each period and pooled within the period. During the five days of each collection period, clean faecal grab samples were taken from four (experiment 1) and 


\section{Khalili, H. et al. Protein supplements for organic milk production}

Table 2. Composition ( $\mathrm{g} \mathrm{kg}^{-1}$ dry matter (DM)) and calculated feeding values of experimental concentrates (experiment 2).

\begin{tabular}{|c|c|c|c|}
\hline & RSC & ORSC & RSCO \\
\hline \multicolumn{4}{|l|}{ Concentrate (C) $\left(\mathrm{g} \mathrm{kg}^{-1} \mathrm{DM}\right)$} \\
\hline Oat & 392 & 373 & 392 \\
\hline Barley & 392 & 373 & 392 \\
\hline Rapeseed cake $^{1}\left(\mathrm{~g} \mathrm{~kg}^{-1} \mathrm{DM}\right)$ & 216 & - & 216 \\
\hline Rapeseed cake $^{2}\left(\mathrm{~g} \mathrm{~kg}^{-1} \mathrm{DM}\right)$ & - & 254 & - \\
\hline Rapeseed oil ${ }^{3}$ (kg DM) & - & - & 0.38 \\
\hline Crude protein $\left(\mathrm{g} \mathrm{kg} \mathrm{DM}^{-1}\right)$ & 167 & 166 & 167 \\
\hline $\mathrm{HCl}-$ fat $\left(\mathrm{g} \mathrm{kg} \mathrm{DM}^{-1}\right)$ & 59 & 100 & 59 \\
\hline $\mathrm{NDF}^{4}\left(\mathrm{~g} \mathrm{~kg} \mathrm{DM}^{-1}\right)$ & 258 & 244 & 258 \\
\hline $\operatorname{AAT}^{5}\left(\mathrm{~g} \mathrm{~kg} \mathrm{DM}^{-1}\right)$ & 112 & 106 & 112 \\
\hline $\mathrm{PBV}^{6}\left(\mathrm{~g} \mathrm{~kg} \mathrm{DM}^{-1}\right)$ & 6 & 20 & 6 \\
\hline $\mathrm{ME}^{7}\left(\mathrm{MJ} \mathrm{kg} \mathrm{DM}^{-1}\right)$ & 12.9 & 13.5 & 12.9 \\
\hline
\end{tabular}

$\mathrm{RSC}=$ concentrate $(\mathrm{C})+$ rapeseed cake; $\mathrm{ORSC}=\mathrm{C}+$ organic rapeseed cake; $\mathrm{RSCO}=\mathrm{C}+$ rapeseed cake+rapeseed oil.

${ }^{1}$ oil removed by pressing and a subsequent heat-moisture treatment (Öpex-treatment).

${ }^{2}$ ecologically produced and cold-pressed.

${ }^{3}$ oil supplement to balance differences in fat content between diets ORSC and RSCO

${ }^{4}$ Neutral detergent fibre.

${ }^{5}$ Amino acids absorbed from the small intestine.

${ }^{6}$ Protein balance value.

${ }^{7}$ Metabolizable energy.

5,6,7 The values derived from feed tables (Tuori et al. 1995).

from six (experiment 2) cows at 0600 and 1600, and pooled within each cow and frozen. Pooled samples were subsequently thawed and dried at $60^{\circ} \mathrm{C}$ and stored at room temperature for chemical analysis. Samples of feeds and faeces were analysed for organic matter by ashing at $600^{\circ} \mathrm{C}$ for $12 \mathrm{~h}$, nitrogen (Kjeldahl-N) and neutral detergent fibre (NDF) (Robertson and Van Soest 1981). Fat was extracted with diethyl ether (AOAC 1990) after boiling for $1 \mathrm{~h}$ in $3 \mathrm{~N} \mathrm{HCl}$. Silage fermentation quality was determined as described by Huhtanen and Heikkilä (1996). Diet digestibility was measured using acid insoluble ash (AIA) as an internal marker (Van Keulen and Young 1977). Milk samples were taken during four consecutive milking on days 17 and 18 of each period and analysed for fat, protein and lactose by an infra-red milk analyser and milk urea content as ammonia (McCullough 1967) after hydrolysis by urease.

\section{Calculations and statistical methods}

Intake of metabolizable energy (ME) and supply of amino acids absorbed from the small intestine (AAT) were calculated according to Finnish feed tables (Tuori et al. 1995). ME intake was also calculated based on intake of digestible organic matter (DOM) (AIA method) assuming ME content of $16 \mathrm{MJ} \mathrm{kg}^{-1} \mathrm{DOM}$ (MAFF 1984), and corrections were made for the difference in the fat intake.

Data from both experiments were analysed by SAS Systems for Linear Models for a Latin square design (Littell et al. 1992). The model was:

$\mathrm{y}_{\mathrm{ij} / \mathrm{km}}=\underset{\mathrm{f}_{\mathrm{ijk} k \mathrm{~m}}}{\mu}+\mathrm{B}_{\mathrm{i}}, \mathrm{C}_{\mathrm{J}}\left(\mathrm{B}_{\mathrm{i}}\right)+\mathrm{P}_{\mathrm{k}}+\mathrm{D}_{1}+\mathrm{PxB}_{\mathrm{ki}}+\mathrm{DxB}_{\mathrm{li}}+$

where $\mu$ is the overall mean, $\mathrm{B}, \mathrm{C}$ and $\mathrm{P}$ are the random effects of block, cow and period, respectively, D is the fixed effect of treatments and $f_{i j l k m}$ is the random error term. The model used for calculating digestibility data from experiment 1 did not include block because there was only one square. In experiment 1 , treatment effects were further separated into single degree comparisons using contrasts. The three contrasts were: effect of common commercial protein supplement (C diet vs. RSM), comparison of RSM with organic protein supplements (RSM vs. P and PRS) and effect of inclusion of rapeseed with pea (P vs. PRS). In experiment 2, pair wise comparisons were performed based on the least significant difference (LSD T-tests) procedure. For experiments 1 and 2, two different but very common commercial rapeseed feeds in Finland were used to minimize the effects of different amounts of fat between experimental feeds. In experiment 1, a low fat RSM was used because pea had a low fat content. In experiment 2, a higher fat RSC was used since cold-pressed rapeseed cake had high fat content. RSCO diet was included in order to study the effects of higher fat content 
Vol. 8 (1999): 239-252.

Table 3. Chemical composition ( $\left.\mathrm{g} \mathrm{kg}^{-1}\right)$ and feeding values of the feeds (experiment 1 ).

\begin{tabular}{lccccc}
\hline & Silage $^{1}$ & Concentrate $^{2}$ & $\begin{array}{c}\text { Rapeseed } \\
\text { meal }\end{array}$ & $\begin{array}{c}\text { Field pea } \\
\text { organic }\end{array}$ & $\begin{array}{c}\text { Rapeseed } \\
\text { organic }\end{array}$ \\
\hline $\begin{array}{l}\text { Dry Matter }\left(\mathrm{g} \mathrm{kg}^{-1}\right) \\
\text { In dry matter }\left(\mathrm{g} \mathrm{kg}^{-1}\right)\end{array}$ & 298 & 861 & 887 & 854 & 894 \\
$\quad \mathrm{OM}^{3}$ & 908 & 970 & 924 & 970 & 952 \\
$\quad \mathrm{Crude}^{3}$ protein & 141 & 135 & 369 & 243 & 228 \\
$\quad \mathrm{HCl}^{-f a t}$ & 44 & 39 & 62 & 15 & 418 \\
$\mathrm{NDF}^{4}$ & 540 & 299 & 277 & 159 & 222 \\
$\mathrm{AAT}^{5}\left(\mathrm{~g} \mathrm{~kg}^{-1}\right)$ & 81 & 100 & 157 & 122 & 65 \\
$\mathrm{PBV}^{6}\left(\mathrm{~g} \mathrm{~kg}^{-1}\right)$ & 4 & -33 & 146 & 33 & 131 \\
$\mathrm{ME}^{7}\left(\mathrm{MJ} \mathrm{kg}^{-1}\right)$ & 10.4 & 13.0 & 11.3 & 13.6 & 18.8 \\
\hline
\end{tabular}

${ }^{1}$ In silage: $\mathrm{pH} 3.98$; in dry matter $\left(\mathrm{g} \mathrm{kg}^{-1}\right)$ : water-soluble carbohydrates 24.4 ; lactic acid 67.5 ; acetic acid 14.7; in total $\mathrm{N}\left(\mathrm{g} \mathrm{kg}^{-1}\right)$ : ammonia $\mathrm{N} 47.8$; soluble $\mathrm{N} 439$. In vitro cellulase digestibility of silage OM 0.700. ${ }^{2} \mathrm{C}=$ concentrate mixture of oats and barley. ${ }^{3} \mathrm{OM}=$ organic matter; ${ }^{4} \mathrm{NDF}=$ neutral detergent fibre. ${ }^{5} \mathrm{Amino}$ acids absorbed from the small intestine. ${ }^{6}$ Protein balance value, calculated using effective protein degradability (EPD) value 82 for silage and EPD values from feed tables (Tuori et al. 1995) for other feeds. ${ }^{7}$ Metabolizable energy., ${ }^{5,7}$ The values derived from feed tables (Tuori et al. 1995).

of organic cold-pressed rapeseed cake compared with commercial rapeseed cake.

\section{Results}

\section{Experiment 1}

The fat content of rapeseed was higher than other protein feeds (Table 3). Generally chemical composition of experimental feeds were typical.

There was no difference $(\mathrm{P}>0.05)$ in silage intake (Table 4). Among protein supplements supply of AAT was highest $(\mathrm{P}<0.05)$ and digestibility of $\mathrm{OM}$ and NDF were lowest $(\mathrm{P}<0.05)$ with RSM diet. Partial replacement of pea with rapeseed (PRS diet) decreased AAT supply $(\mathrm{P}<0.01)$, but improved fat digestion $(\mathrm{P}<0.001)$ compared with pea without rapeseed (P diet).

RSM diet increased $(\mathrm{P}<0.05)$ yields of energy corrected milk (ECM), milk and milk protein and milk urea content, but decreased $(\mathrm{P}<0.001)$ $\mathrm{N}$ utilization ( $\mathrm{N}$ in milk $\mathrm{N}^{-1}$ intake) compared with $\mathrm{C}$ diet (Table 5). Milk protein content was higher $(\mathrm{P}<0.05)$ with $\mathrm{RSM}$ than with organic protein supplements. Replacing part of field pea with rapeseed (PRS diet) resulted in increased yields of ECM and fat and improved feed efficiency $(\mathrm{P}<0.05)$, but decreased milk protein and urea content compared with $\mathrm{P}$ diet.

\section{Experiment 2}

Chemical composition of rapeseed cake was typical (Table 6). The nitrogen content of organic cold-pressed rapeseed cake was lower, but the fat content was higher than that of commercial rapeseed cake. In both experiments, grass-red clover silages had low proportions of soluble $\mathrm{N}$ (Kjeldahl-N) in total $\mathrm{N}$ which is typical due to reduced proteolysis during ensiling of red clover-grass silage (Jones et al. 1995).

Silage intake was similar between commercial RSC and organic ORSC diets, but fat intake and digestibility were higher (at least $\mathrm{P}<0.05$ ) with ORSC diet (Table 7). Inclusion of oil with RSC decreased $(\mathrm{P}<0.05)$ intakes of silage and consequently that of nitrogen and AAT, but improved nitrogen and fat digestibility.

Increased (at least $\mathrm{P}<0.05$ ) nitrogen utilization due to a lower nitrogen intake with organic ORSC diet compared with RSC diet was the only 


\section{Khalili, H. et al. Protein supplements for organic milk production}

Table 4. Effect of different diets on feed intake, estimated consumption of metabolizable energy (ME) and amino acids absorbed from the small intestine (AAT) consumption and digestibility (experiment 1, digestibility data for 4 cows used).

\begin{tabular}{|c|c|c|c|c|c|c|c|c|}
\hline & \multicolumn{4}{|c|}{ Diets } & \multirow[b]{2}{*}{ SEM } & \multicolumn{3}{|c|}{ Significance of effect } \\
\hline & $\mathrm{C}^{1}$ & RSM & $\mathrm{P}$ & PRS & & $\begin{array}{l}\text { C vs. } \\
\text { RSM }\end{array}$ & $\begin{array}{l}\text { RSM vs. } \\
\text { P\&PRS }\end{array}$ & $\begin{array}{l}\text { P vs. } \\
\text { PRS }\end{array}$ \\
\hline \multicolumn{9}{|c|}{ Feed intake (kg dry matter day $\left.{ }^{-1}\right)$} \\
\hline Silage & 12.77 & 13.11 & 13.46 & 13.09 & 0.229 & & & \\
\hline Supplement & 6.84 & 7.10 & 6.83 & 6.94 & & & & \\
\hline Total intake & 19.61 & 20.21 & 20.30 & 20.02 & 0.231 & \multicolumn{3}{|l|}{$\mathrm{P}=0.09$} \\
\hline $\mathrm{N}$ intake $\left(\mathrm{kg} \mathrm{day}^{-1}\right)$ & 0.432 & 0.507 & 0.504 & 0.502 & 0.0055 & $* * *$ & & \\
\hline $\mathrm{HCl}$-fat intake $\left(\mathrm{kg} \mathrm{day}^{-1}\right)$ & 0.83 & 0.89 & 0.78 & 1.20 & 0.010 & $* * *$ & $* * *$ & $* * *$ \\
\hline $\operatorname{ME}^{2}\left(\mathrm{MJ} \mathrm{day}^{-1}\right)$ & 206.2 & 212.3 & 217.1 & 219.9 & 2.61 & & & \\
\hline $\operatorname{ME}^{3}\left(\mathrm{MJ} \mathrm{day}^{-1}\right)$ & 221.7 & 225.8 & 230.9 & 233.9 & 2.41 & & $*$ & \\
\hline $\operatorname{AAT}^{4}\left(\mathrm{~g} \mathrm{day}^{-1}\right)$ & 1718 & 1860 & 1842 & 1765 & 18.7 & $* * *$ & $*$ & $* *$ \\
\hline $\mathrm{PBV}^{5}\left(\mathrm{~g} \mathrm{day}^{-1}\right)$ & -175 & 95 & 33 & 149 & 0.9 & $* * *$ & $* *$ & $* * *$ \\
\hline \multicolumn{9}{|l|}{ Digestibility } \\
\hline Dry matter & 0.686 & 0.686 & 0.698 & 0.694 & 0.0037 & & $\mathrm{P}=0.07$ & \\
\hline Organic matter & 0.708 & 0.708 & 0.720 & 0.716 & 0.0035 & & $*$ & \\
\hline $\mathrm{N}$ & 0.630 & 0.666 & 0.658 & 0.658 & 0.0079 & $*$ & & \\
\hline $\mathrm{HCl}$-fat & 0.574 & 0.593 & 0.541 & 0.607 & 0.0133 & & & $* *$ \\
\hline $\mathrm{NDF}^{6}$ & 0.620 & 0.617 & 0.638 & 0.641 & 0.0064 & & $*$ & \\
\hline
\end{tabular}

Statistical significance: $* \mathrm{P}<0.05 ; * * \mathrm{P}<0.01 ; * * * \mathrm{P}<0.001, \mathrm{SEM}=$ standard error of mean.

${ }^{1} \mathrm{C}=$ concentrate mixture; $\mathrm{RSM}=\mathrm{C}+$ rapeseed meal; $\mathrm{P}=\mathrm{C}+$ pea; $\mathrm{PRS}=\mathrm{C}+$ pea+rapeseed.

${ }^{2}$ Calculated from the intake of digestible organic matter determined in cows using acid insoluble ash as an internal marker.

${ }^{3,4}$ Calculated using values from feed tables (Tuori et al. 1995). ${ }^{5}$ Protein balance value. ${ }^{6} \mathrm{NDF}=$ neutral detergent fibre.

significant difference between these diets (Table 8). Adding oil with RSC increased yields of milk and lactose $(\mathrm{P}<0.05)$, but decreased protein content compared with RSC diet without oil. Decreased silage intake increased feed efficiency and $\mathrm{N}$ utilization with RSCO diet compared to RSC diet.

\section{Discussion}

\section{Feed intake and digestibility}

\section{Experiment 1}

Increased proportion of protein in the concentrate has been shown to increase silage intake (Thomas and Rae 1988). In recent studies a re- placement of energy supplement with rapeseed meal has increased silage dry matter intake 0.247 kg per kg RSM (Huhtanen 1998). Here the corresponding increase of $0.225 \mathrm{~kg}$ in silage intake per kg RSM was similar to that observed with grass silage-based diets in conventional milk production. However, in the present experiment this increment was not significant. With organic protein supplements silage intake was consistent with commercial RSM. According to Oldham and Smith (1982) and Thomas and Rae (1988), increases in dietary crude protein content generally increase dry matter digestibility. Here RSM did not improve organic matter digestibility compared with $\mathrm{C}$ diet, which is in agreement with data of Tuori (1992) and Huhtanen (1998). Furthermore, RSM had slightly lower organic matter digestibility compared with the other two protein supplements. RSM has a 
Vol. 8 (1999): 239-252.

Table 5. Effects of different diets on milk yield, composition, yield of milk constituents, feed efficiency and utilization of $\mathrm{N}$ for milk production (experiment 1).

\begin{tabular}{|c|c|c|c|c|c|c|c|c|}
\hline & \multicolumn{4}{|c|}{ Diets } & \multirow[b]{2}{*}{ SEM } & \multicolumn{3}{|c|}{ Significance of effect } \\
\hline & $\mathrm{C}^{1}$ & RSM & $\mathrm{P}$ & PRS & & $\begin{array}{l}\text { C vs. } \\
\text { RSM }\end{array}$ & $\begin{array}{l}\text { RSM vs. } \\
\text { P\&PRS }\end{array}$ & $\begin{array}{l}\text { P vs. } \\
\text { PRS }\end{array}$ \\
\hline $\mathrm{ECM}^{2}$ yield $\left(\mathrm{kg}\right.$ day $\left.^{-1}\right)$ & 24.6 & 25.6 & 25.1 & 26.3 & 0.32 & $*$ & & $*$ \\
\hline Milk yield $\left(\mathrm{kg} \mathrm{day}^{-1}\right)$ & 24.0 & 25.0 & 25.2 & 25.9 & 0.33 & $*$ & & \\
\hline \multicolumn{9}{|l|}{ Milk composition $\left(\mathrm{g} \mathrm{kg}^{-1}\right)$} \\
\hline fat & 43.3 & 42.6 & 41.0 & 42.7 & 0.89 & & & \\
\hline protein & 31.4 & 32.6 & 32.1 & 31.0 & 0.35 & $*$ & $*$ & $*$ \\
\hline lactose & 47.9 & 47.8 & 47.8 & 47.9 & 0.13 & & & \\
\hline urea $\left(\mathrm{mg} \mathrm{kg}^{-1}\right)$ & 241 & 309 & 314 & 288 & 6.2 & $* * *$ & & $* *$ \\
\hline \multicolumn{9}{|c|}{ Yield of milk constituents $\left(\mathrm{g} \mathrm{day}^{-1}\right)$} \\
\hline fat & 1030 & 1055 & 1022 & 1100 & 21.6 & & & $*$ \\
\hline protein & 750 & 810 & 805 & 802 & 9.6 & $* * *$ & & \\
\hline lactose & 1152 & 1197 & 1200 & 1235 & 16.0 & $\mathrm{P}=0.07$ & & \\
\hline \multicolumn{9}{|l|}{ Feed efficiency } \\
\hline ECM kg-1 dry matter & 1.27 & 1.28 & 1.25 & 1.34 & 0.016 & & & $* *$ \\
\hline \multicolumn{9}{|l|}{$\mathrm{N}$ utilization } \\
\hline $\mathrm{N}$ in milk $\mathrm{N}^{-1}$ intake & 0.274 & 0.253 & 0.253 & 0.254 & 0.0036 & $* * *$ & & \\
\hline
\end{tabular}

Statistical significance: $* \mathrm{P}<0.05 ; * * \mathrm{P}<0.01 ; * * * \mathrm{P}<0.001, \mathrm{SEM}=$ standard error of mean.

${ }^{1} \mathrm{C}=$ concentrate; $\mathrm{RSM}=\mathrm{C}+$ rapeseed meal; $\mathrm{P}=\mathrm{C}+$ pea; $\mathrm{PRS}=\mathrm{C}+$ pea+rapeseed.

${ }^{2} \mathrm{ECM}=$ energy corrected milk (Sjaunja et al. 1990).

Table 6. Chemical composition $\left(\mathrm{g} \mathrm{kg}^{-1}\right)$ and feeding values of the feeds (experiment 2).

\begin{tabular}{|c|c|c|c|c|}
\hline & Silage $^{1}$ & Concentrate $^{2}$ & $\begin{array}{l}\text { Organic rapeseed } \\
\text { cake }\end{array}$ & $\begin{array}{l}\text { Rapeseed } \\
\text { cake }\end{array}$ \\
\hline Dry Matter $\left(\mathrm{g} \mathrm{kg}^{-1}\right)$ & 287 & 860 & 891 & 882 \\
\hline \multicolumn{5}{|l|}{ In dry matter $\left(\mathrm{g} \mathrm{kg}^{-1}\right)$} \\
\hline $\mathrm{OM}^{3}$ & 911 & 969 & 937 & 924 \\
\hline Crude protein & 198 & 116 & 309 & 346 \\
\hline $\mathrm{HCl}-\mathrm{fat}$ & 52 & 48 & 248 & 99 \\
\hline $\mathrm{NDF}^{4}$ & 540 & 246 & 234 & 296 \\
\hline $\operatorname{AAT}^{5}\left(\mathrm{~g} \mathrm{~kg}^{-1}\right)$ & 86 & 100 & 125 & 157 \\
\hline $\mathrm{PBV}^{6}\left(\mathrm{~g} \mathrm{~kg}^{-1}\right)$ & 51 & -33 & 172 & 146 \\
\hline $\mathrm{ME}^{7}\left(\mathrm{MJ} \mathrm{kg}^{-1}\right)$ & 10.5 & 13.0 & 15.1 & 12.6 \\
\hline
\end{tabular}

${ }^{1}$ In silage: $\mathrm{pH} 4.00$; in dry matter $\left(\mathrm{g} \mathrm{kg}^{-1}\right)$ : water-soluble carbohydrates 12.5 ; lactic acid 68.0; acetic acid 18.3; in total $\mathrm{N}\left(\mathrm{g} \mathrm{kg}^{-1}\right)$ : ammonia N 36.0; soluble $\mathrm{N} 487$. In vitro cellulase digestibility of silage $\mathrm{OM}=0.699$. ${ }^{2} \mathrm{C}=$ concentrate mixture of oats and barley. ${ }^{3} \mathrm{OM}=$ organic matter; ${ }^{4} \mathrm{NDF}=$ neutral detergent fibre. ${ }^{5} \mathrm{Amino}$ acids absorbed from the small intestine. ${ }^{6}$ Protein balance value, calculated using effective protein degradability (EPD) value 82 for silage and EPD values from feed tables (Tuori et al. 1995) for other feeds. ${ }^{7}$ Metabolizable energy., ${ }^{5,6}$ The values derived from feed tables (Tuori et al. 1995). 


\section{Khalili, H. et al. Protein supplements for organic milk production}

Table 7. Effect of different diets on feed intake, estimated consumption of metabolizable energy (ME) and amino acids absorbed from the small intestine (AAT) and digestibility (experiment 2, digestion data for 6 cows used).

\begin{tabular}{|c|c|c|c|c|}
\hline & \multicolumn{3}{|c|}{ Diets } & \multirow[b]{2}{*}{ SEM } \\
\hline & $\mathrm{RSC}$ & ORSC & RSCO & \\
\hline \multicolumn{5}{|c|}{ Feed intake (kg dry matter day $\left.{ }^{-1}\right)$} \\
\hline Silage & $14.15^{\mathrm{a}}$ & $13.87^{\mathrm{ab}}$ & $12.59^{\mathrm{b}}$ & 0.383 \\
\hline Supplement & 6.83 & 6.70 & 7.26 & \\
\hline Total intake & 20.98 & 20.57 & 19.85 & 0.344 \\
\hline $\mathrm{N}$ intake $\left(\mathrm{kg} \mathrm{day}^{-1}\right)$ & $0.630^{\mathrm{a}}$ & $0.616^{\mathrm{ab}}$ & $0.582^{b}$ & 0.0109 \\
\hline $\mathrm{HCl}$-fat intake $\left(\mathrm{kg} \mathrm{day}^{-1}\right)$ & $1.14^{\mathrm{a}}$ & $1.39^{\mathrm{b}}$ & $1.44^{\mathrm{b}}$ & 0.015 \\
\hline $\mathrm{ME}^{1}\left(\mathrm{MJ} \mathrm{day}^{-1}\right)$ & 211.5 & 216.4 & 206.7 & 4.75 \\
\hline $\mathrm{ME}^{2}\left(\mathrm{MJ} \mathrm{day}^{-1}\right)$ & 236.7 & 236.1 & 232.7 & 3.49 \\
\hline $\mathrm{AAT}^{2}\left(\mathrm{~g} \mathrm{day}^{-1}\right)$ & $1984^{\mathrm{a}}$ & $1906^{\mathrm{ab}}$ & $1856^{\mathrm{b}}$ & 29.1 \\
\hline $\mathrm{PVB}^{3}\left(\mathrm{~g}\right.$ ay $\left.^{-1}\right)$ & $763^{\mathrm{b}}$ & $841^{\mathrm{a}}$ & $684^{c}$ & 18.2 \\
\hline \multicolumn{5}{|l|}{ Digestibility } \\
\hline Dry matter & 0.654 & 0.662 & 0.670 & 0.0051 \\
\hline Organic matter & 0.682 & 0.689 & 0.691 & 0.0047 \\
\hline $\mathrm{N}$ & $0.633^{\mathrm{a}}$ & $0.664^{\mathrm{b}}$ & $0.664^{b}$ & 0.0078 \\
\hline $\mathrm{HCl}$-fat & $0.620^{\mathrm{a}}$ & $0.675^{\mathrm{b}}$ & $0.701^{b}$ & 0.0137 \\
\hline $\mathrm{NDF}^{4}$ & 0.596 & 0.603 & 0.596 & 0.0089 \\
\hline
\end{tabular}

Statistical significance: ${ }^{a, b, c}$ Means in a row with different superscripts are significantly different (at least $\mathrm{P}<0.05)$. SEM=standard error of mean.

$\mathrm{RSC}=$ concentrate $(\mathrm{C})+$ rapeseed cake; $\mathrm{ORSC}=\mathrm{C}+$ organic rapeseed cake; $\mathrm{RSCO}=\mathrm{C}+$ rapeseed cake+rapeseed oil. ${ }^{1}$ Calculated from the intake of digestible organic matter determined in cows using acid insoluble ash as an internal marker. ${ }^{2,3}$ Calculated using values from feed tables (Tuori et al. 1995). ${ }^{3}$ Protein balance value. ${ }^{4} \mathrm{NDF}=$ neutral detergent fibre.

lower D-value than other components of concentrates (Tuori et al. 1995). In harmony with earlier studies (Huhtanen 1998), RSM did not improve NDF digestibility. Higher NDF digestibility with field pea containing diets are probably due to changes in NDF composition rather than as a result of changes in rumen cellulolytic activity. Cell walls of barley and oats are poorly digested, whereas cell walls of pea are highly digestible. Although AAT supply (corrected for negative $\mathrm{PBV}$ ) was more than AAT requirements for maintenance and milk production with the control diet, RSM diet slightly increased silage intake. One reason for increased silage intake with RSM could be the increased supply of AAT and an improved balance of AAT. Post-ruminal casein infusion has increased the intake of red clover silage more than ruminal infusion (Khalili et al. 1995b). Post-ruminal metabolism and/ or increased rumen NDF fill affected intake with duodenal infusion. According to Heikkilä et al. (1998) there was a close relationship between AAT content of the diet and silage intake. In spite of high fat content of crushed rapeseed, silage intake was not decreased with PRS diet compared to the control or $\mathrm{P}$ diet $(\mathrm{P}>0.05)$. Here inclusion of $1.07 \mathrm{~kg}$ DM (fat $418 \mathrm{~g} \mathrm{~kg}^{-1} \mathrm{DM}$ ) of rapeseed did not impair NDF digestibility. In an earlier study (Steele 1985) addition of $1.9 \mathrm{~kg}$ (oil content $194 \mathrm{~g} \mathrm{~kg}^{-1}$ ) crushed soybeans decreased silage intake compared with a silage and soybean meal diet. 
Vol. 8 (1999): 239-252.

Table 8. Effects of different diets on milk yield, composition, yield of milk constituents, feed efficiency and utilization of $\mathrm{N}$ for milk production (experiment 2).

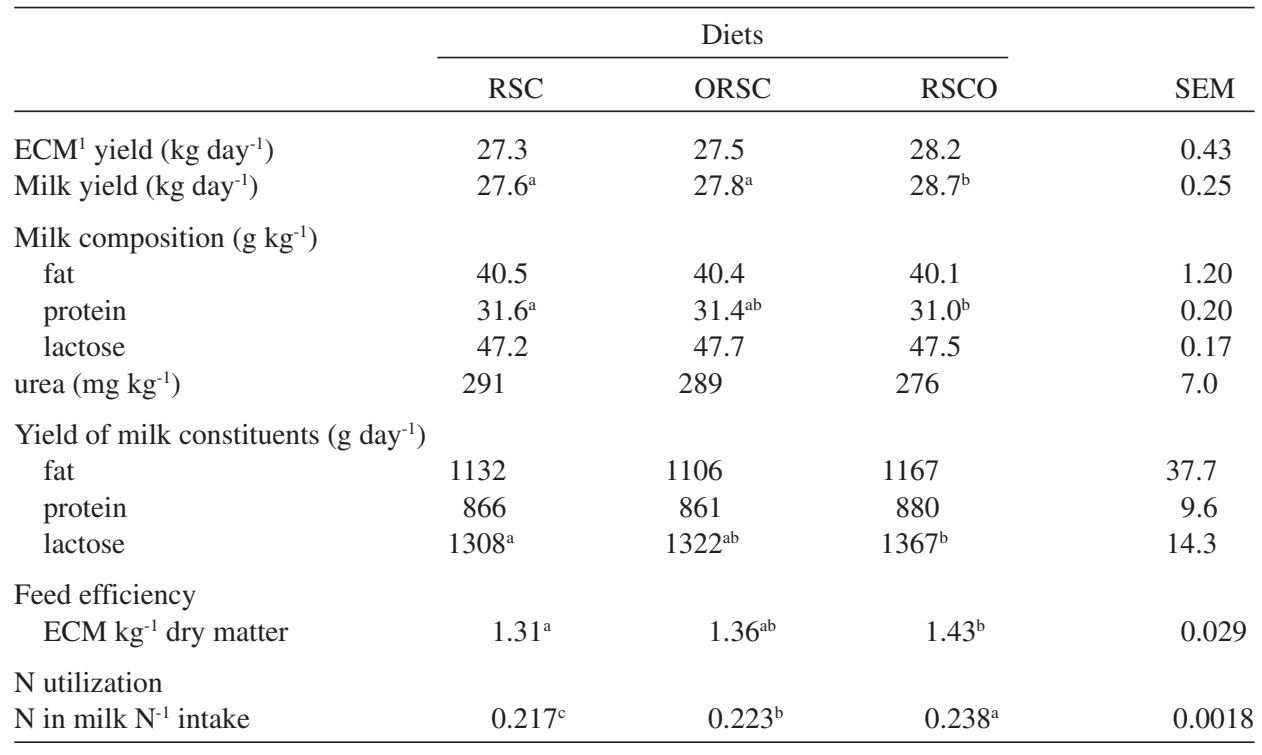

Statistical significance: ${ }^{\mathrm{a}, \mathrm{b}, \mathrm{c}}$ Means in a row with different superscripts are significantly different (at least $\mathrm{P}<0.05)$. SEM=standard error of mean.

$\mathrm{RSC}=$ concentrate $(\mathrm{C})+$ rapeseed cake; $\mathrm{ORSC}=\mathrm{C}+$ organic rapeseed cake; $\mathrm{RSCO}=\mathrm{C}+$ rapeseed cake + rapeseed oil. ${ }^{1} \mathrm{ECM}=$ energy corrected milk (Sjaunja et al. 1990).

\section{Experiment 2}

There was no difference in silage intake between commercial heat-moisture treated RSC and organic non-treated ORSC supplements. Rinne et al. (1999) reported similar silage intakes between RSM and heat-moisture treated RSC. These experiments show no benefits in silage intake when rapeseed cake is heat-moisture treated to reduce protein degradability in the rumen. High concentrations of supplementary fat have often decreased feed DM intake though this is not always the case (Coppock and Wilks 1991). Here higher fat content of organic ORSC did not significantly decrease silage intake compared with RSC. However, when oil was added with RSC, silage intake was reduced in agreement with Steele (1985) and Mohamed et al. (1988). Fat inclusion has reduced the digestibility of $\mathrm{OM}$ and fibre (Palmquist and Jenkins 1980, Tesfa 1992, Jenkins 1993, Khalili et al. 1997). Here the rea- son for decreased silage intake was not decreased digestibility of OM or NDF. Fat digestibility was increased with the ORSC and RSCO diets compared with the RSC diet in agreement with Khalili et al. (1997).

\section{Animal performance}

There were differences in the protein contents of silages. Huhtanen (1998) concluded in his review that RSM in the diet has produced similar increases in milk protein yield over a wide range of silage CP contents. Depending on a given situation, protein supplements can cause different responses due to e.g. differences in supply of AA and/or AA profile and/or rumen degradability. Recently, Huhtanen (1998) discussed protein evaluation and concluded that in studies carried out after the AAT - PBV system was 


\section{Khalili, H. et al. Protein supplements for organic milk production}

adopted in Finland, the relationship between AAT supply calculated using feed table values (Tuori et al. 1995) and milk protein yield has been very close. Current results are discussed in relation to the Finnish AAT -PBV system.

\section{Experiment 1}

Rapeseed meal and cake are excellent protein supplements for grass silage-based diets in conventional milk production (Tuori 1992, Huhtanen and Heikkilä 1996, Huhtanen 1998, Rinne et al. 1999, Ahvenjärvi et al. 1999). In the present experiment cows improved milk yield $0.66 \mathrm{~kg}$ per $\mathrm{kg}$ RSM DM compared with the control diet. This was close to the mean value of 0.77 per $\mathrm{kg}$ RSM DM concluded by Tuori (1992) but much lower than the mean value of 1.05 per $\mathrm{kg}$ RSM as fed by Huhtanen (1998) with grass silage-based diets. Tuori (1992) and Huhtanen (1998) concluded that increased ME intake was one explanation for the increased milk production. Here milk yield increased $0.16 \mathrm{~kg}$ milk per each additional MJ ME (estimated using DOM) consumed with RSM diet indicating that additional ME intake was in line with increased milk yield. Estimated ME utilization for milk production was not affected by RSM (Huhtanen and Heikkilä 1996, Rinne et al. 1999). RSM diet did not affect feed efficiency here.

Post-ruminal casein infusion increased yields of milk and protein more than ruminal casein infusion when cows were given a red clovergrass silage diet (Khalili et al. 1995a). In agreement with recent reviews (Tuori 1992, Huhtanen 1998), RSM increased milk protein yield $36 \mathrm{~g}$ per kg RSM DM. Tuori (1992) reported a mean response of $29 \mathrm{~g}$ increase in protein yield per $\mathrm{kg}$ RSM DM and Huhtanen (1998) 39 g per kg RSM as fed. RSM here caused a positive response in milk yield although AAT supply was higher than requirements (for maintenance and milk production) and milk urea was in the normal range of the control diet. Increased milk production indicated a sub-optimal AAT balance with grass-red clover silage supplemented with oats and barley. Therefore, with RSM diet, improved balance of absorbed AAT was most probably one reason for the increased production of milk and protein. RSM is a good source of histidine and Vanhatalo et al. (1997) reported that histidine appears to be the first limiting amino-acid for milk protein production on grass silage based diets.

Organic protein supplements produced at least as much milk and milk protein as RSM. Milk yield increased 0.11 and $0.14 \mathrm{~kg}$ milk per additional MJ ME with P and PRS diets, respectively. These increments were clearly less than theoretical considerations of 0.19 (Tuori et al. 1995). Pea increased milk protein yield $18 \mathrm{~g}$ per $\mathrm{kg}$ pea DM due to a low protein content. Field pea has shown promising results in earlier experiments (Syrjälä-Qvist et al. 1981, Corbett et al. 1995, Khorasani and Kennelly 1997, Heikkilä and Toivonen 1997). In the study of Syrjälä-Qvist et al. (1981) replacing soybean meal with pea did not affect milk production or composition. Corbett et al. (1995) reported that pea can be substituted for soybean and canola meal as a protein source for high-producing cows fed lucerne and grain. Similarly in two recent experiments replacement of oats either with rapeseed meal or with pea caused no differences in milk yields but in one experiment protein yield was lower with the pea diet (Heikkilä and Toivonen 1997). In spite of the higher protein degradability of pea (soluble protein fraction was 58.6 $\%$ by Khorasani and Kennelly 1997) than that of rapeseed meal (soluble protein was $13.3 \%$ by Rinne et al. 1999) there was only a minor difference in AAT content between concentrate mixtures in P and RSM diets. High protein degradation of pea may have stimulated microbial protein synthesis and consequently contributed to observed milk production. Ruminal bacterial $\mathrm{N}$ yield was higher when replacement of soybean meal protein by pea protein increased (Khorasani and Kennelly 1997). In addition, pea contains histidine which is an important AA for grass silage based-diets as mentioned earlier but the methionine content of pea is low. On the other hand, according to Varvikko et al. (1996) abomasal infusion of methionine did not improve milk production on grass silage based diets. 
Vol. 8 (1999): 239-252.

ECM yield was higher when a combination of pea and rapeseed was fed but protein content was clearly lower and consequently protein yield was similar as with P diet. There are ample results showing that feeding moderate amounts of fat increases milk production. In contrast, Steele (1985) reported that addition of crushed soybeans with silage based diets decreased milk production and protein content compared with soybean oil meal diet. ME intakes were similar between $\mathrm{P}$ and PRS diets indicating that ME intake did not explain the higher ECM production or lower milk protein content with PRS diet. The increase in ECM yield with PRS diet had some dilution effect (Wu and Huber 1994) for milk protein content. The fat content of rapeseed might also have reduced microbial protein synthesis as suggested by Mohamed et al. (1988). The supply of AAT was lower with the PRS diet. This affected the balance between energy and protein which might have contributed to the lower protein content with PRS diet.

\section{Experiment 2}

AAT supplies were much higher than requirements (for maintenance and milk production) and values of PBV and milk urea were high with all diets in the present experiment. Theoretically reduced ruminal protein degradability of RSC could have increased supply of histidine, the first limiting amino acid with grass silage based diets (Vanhatalo et al. 1997), and consequently increased milk production compared with coldpressed untreated rapeseed cake. There was, however, no differences in milk yield or composition between these two diets. This discrepancy between estimated protein value based on ruminal degradability, and milk production response was recently studied by Rinne et al. (1999). They compared RSM meal and heatmoisture treated RSC and did not notice any differences in milk production and milk constituent output. Also non-ammonia $\mathrm{N}$ flows from the rumen have been found to be similar for the two rapeseed feeds (Ahvenjärvi et al. 1999). The present results confirmed their earlier observa- tions that estimation of AAT content based on rumen degradation can be misleading.

Effects of fat supplementation have been variable and both positive and negative results have been reported in many experiments. Also here the effects of fat were different since higher fat supply with ORSC did not improve milk production compared with RSC. In contrast, although there was no differences in ME intake addition of oil with RSC increased milk yield compared with RSC without oil. Addition of oil/ fatty acids has decreased milk protein content (Mohamed et al. 1988, Tesfa 1992, Khalili et al. 1997) as was observed also with RCSO diet. Here one reason for a decreased protein content was a dilution effect (Wu and Huber 1994) since protein yield was not affected. With the RSCO diet, the supply of AAT was decreased affecting balance between nutrients. This might be one reason for the decreased protein content. Mohamed et al. (1988) reported reduced plasma amino acid concentrations and that the ratio of serum glucose to unsaturated long-chain fatty acids was positively correlated with milk protein content.

\section{Conclusions}

Yields of milk and protein were similar between organic field pea and pea plus rapeseed and commercial RSM. Protein content was decreased when a combination of pea and rapeseed was given compared with pea. Equal amounts of milk and protein were produced when either commercial RSC or organic cold-pressed RSC were fed. However, when oil was added with commercial RSC milk yield increased.

Acknowledgements. The authors are grateful to Ministry of Agriculture and Forestry for financial support. We thank the staff of Siikasalmi research farm at the University of Joensuu and the staff of Animal Production Research at Agricultural Research Centre of Finland. 


\section{Khalili, H. et al. Protein supplements for organic milk production}

\section{References}

Ahvenjärvi, S., Vanhatalo, A., Huhtanen, P. \& Varvikko, T. 1999. Effects of supplementation of a grass silage and barley diet with urea, rapeseed meal and heatmoisture treated rapeseed cake on omasal digesta flow and milk production in lactating dairy cows. Acta Agriculturae Scandinavica Section A, Animal Science 49: $179-189$.

AOAC 1990. Official methods of analysis. Fat (crude) or ether extract in animal feed (920.39). Association of Official Analytical Chemists. $15^{\text {th }}$ Edition. $1141 \mathrm{p}$.

Castle, M.E. 1982. Feeding high-quality silage. In: Rook, J.A.F. \& Thomas, P.C. (eds.). Silage for milk production. National Research Institute for Research in Dairying, Reading/Hannah Research Institute, Ayr, UK. p. 127-150.

Coppock, C.E. \& Wilks, D.L. 1991. Supplemental fat in high-energy rations for lactating cows: effects on intake, digestion, milk yield, and composition. Journal of Animal Science 69: 3826-3837.

Corbett, R.R., Okine, E.K. \& Goonewardene, L.A. 1995. Effects of feeding peas to high-producing dairy cows. Canadian Journal of Animal Science 75: 625-629.

Granstedt, A. 1992. Case studies on the flow and supply of nitrogen in alternative farming in Sweden. I. Skilleby-farm 1981-1987. Biological agriculture and horticulture 9: 15-63.

Heikkilä, T. \& Toivonen, V. 1997. Herne ja rypsirouhe lehmien valkuaisrehuna säilörehuruokinnalla. Kotieläintieteen päivät 1997. Maaseutukeskusten Liiton julkaisuja 914 . p. 187-190.

-, Toivonen, V. \& Mela, T. 1992. Comparison of red clover-grass silage with grass silage for milk production. In: Proceedings of the $14^{\text {th }}$ General Meeting of the European Grassland Federation, Lahti, Finland, June 8-11, 1992. p. 388-391.

-, Toivonen, V. \& Mela, T. 1996. Effects of red clovergrass, grass and annual ryegrass silages with two concentrate protein levels on milk production. In: Parente, G. et al. (eds.). Proceedings of the $16^{\text {th }}$ General Meeting of the European Grassland Federation, Grado (Gorizia), Italy, September 15-19, 1996. p. 447-450.

-, Toivonen, V. \& Huhtanen, P. 1998. Effects of and interactions between the extent of silage fermentation and protein supplementation in lactating dairy cows. Agricultural and Food Science in Finland 7: 329-343.

Huhtanen, P. 1998. Supply of nutrients and productive responses in dairy cows given diets based on restrictively fermented silage. Agricultural and Food Science in Finland 7: 219-250.

- \& Heikkilä, T. 1996. Effects of physical treatment of barley and rapeseed meal in dairy cows given grass silage-based diets. Agricultural and Food Science in Finland 6: 399-412.

Huida, L., Väätäinen, H. \& Lampila, M. 1986. Comparison of dry matter contents in grass silage as determined by oven drying and gas chromatographic water analyses. Annales Agriculturae Fenniae 25: 215230.
Jenkins, T.C. 1993. Lipid metabolism in the rumen. Journal of Dairy Science 76: 3851-3863.

Jones, B.A., Muck, R.E. \& Hatfield, R.D. 1995. Red clover extracts inhibit legume proteolysis. Journal of the Science of Food and Agriculture 67: 329-333.

Khalili, H., Huhtanen, P., Jaakkola, S. \& Varvikko, T. 1995a. The effects of ruminal and duodenal casein infusion on intake of red clover silage, milk production and microbial protein synthesis. Proceedings of the $111^{\text {th }}$ meeting of the British Society of Animal Science, Animal Science 60: 544.

-, Huhtanen, P., Jaakkola, S. \& Varvikko, T. 1995b. The effects of ruminal and duodenal casein infusion on dry matter (DM) intake of red clover silage and rumen pool size, digestion and passage kinetics of neutral detergent fibre (NDF). Annales de Zootechnique 44, Suppl.: 243.

-, Varvikko, T., Toivonen, V., Hissa, K. \& Suvitie, M. 1997. The effects of added glycerol or unprotected free fatty acids or a combination of the two on silage intake, milk production, rumen fermentation and diet digestibility in cows given grass silage based diets. Agricultural and Food Science in Finland 6: 349-362.

Khorasani, G.R. \& Kennelly, J.J. 1997. Peas for ruminants - defining their worth. Feed Mix 5: 30-32.

Littell, R.C., Freund, R.J. \& Spector, P.C. 1992. SAS System for Linear Models. Third Edition. SAS series in statistical applications. $329 \mathrm{p}$.

McCullough, H. 1967. The determination of ammonia in whole blood by a direct colorimetric method. Chimica Acta 17: 297-304.

Ministry of Agriculture and Fisheries (MAFF). 1984. Energy allowances and feeding systems for ruminants. Reference Book 433. Her Majesty's Stationery Office, London. $85 \mathrm{p}$.

Mohamed, O.E., Satter, L.D., Grummer, R.R. \& Ehle, F.R. 1988. Influence of dietary cottonseed and soybean on milk production and composition. Journal of Dairy Science 71: 2677-2688.

Oldham, J.D. \& Smith, T. 1982. Protein-energy interrelationships for growing and for lactating cattle. In: Miller, E.L. et al. (eds.). Protein contribution of feedstuffs for ruminants. Butterworths. p. 103-130.

Palmquist, D.L. \& Jenkins, T.C. 1980 . Fat in lactation rations: review. Journal of Dairy Science 63: 1-14.

Rinne, M., Jaakkola, S., Varvikko, T. \& Huhtanen, P. 1999. Effects of type and amount of rapeseed feed on milk production. Acta Agriculturae Scandinavica, Section A, Animal Science 49: 137-148.

Robertson, J.B. \& Van Soest, P.J. 1981. The detergent system of analysis and its application to human foods. In: James, W.D.T. \& Theander, O. (eds.). The Analyses of Dietary Fibre in Foods. New York, NY, Marcell Dekker, p. 123-158.

Sjaunja, L.O., Baevre, L., Junkkarinen, L., Pedersen, J. \& Setälä, J. 1990. A Nordic proposal for an energy corrected milk (ECM) formula. $27^{\text {th }}$ Session International Committee of Recording and Productivity of Milk Animal. Paris, France p. 156-157. 
Vol. 8 (1999): 239-252.

Steele, W. 1985. High-oil, high-protein diets and milk secretion by cows. Journal of Dairy Science 68: 1409-1415.

Syrjälä-Qvist, L., Setälä, J. \& Tuori, M. 1981. Field peas as a protein source for high-producing dairy cows on grass silage and hay based feeding. Journal of the Scientific Society of Finland 53: 307-313.

Tesfa, A.T. 1992. Rapeseed oil in ruminants diet: its effect on rumen metabolism and animal performance. Academic Dissertation. Department of Animal Science, University of Helsinki, Finland. 53 p.

Thomas, C. \& Rae, R.C. 1988. Concentrate supplementation of silage for dairy cows. In: Garnsworthy, P.C. (ed.). Nutrition and lactation in the dairy cow. Butterworths, London. p. 327-354.

Tuori, M. 1992. Rapeseed meal as a supplementary protein for dairy cows on grass silage-based diet, with the emphasis on the Nordic AAT-PBV feed protein evaluation system. Agricultural Science in Finland 1: 367-439.

-, Kaustell, K. \& Huhtanen, P. 1998. Comparison of the protein evaluation systems of feed for dairy cows. Livestock Production Science 55: 33-46.

-, Kaustell, K., Valaja, J., Aimonen, E., Saarisalo, E. \& Huhtanen, P. 1995. Rehutaulukot ja ruokintasuositukset. (Feed tables and feeding recommendations). Helsinki. 99 p.
Vanhatalo, A., Heikkilä, T. \& Gäddnäs, T. 1995. Microbial protein synthesis in dairy cows fed grass silage or red clover-grass silage. In: Nunes, A.F. et al. (eds.). Protein metabolism and nutrition. Proceedings of the $7^{\text {th }}$ International Symposium on Protein Metabolism and Nutrition, Vale de Santarem, Portugal, May 2427, 1995. EAAP Publication no. 81. p. 275.

-, Huhtanen, P. \& Varvikko, T. 1997. Response of dairy cows fed grass silage based diets to the abomasal infusions of histidine alone or in combinations with methionine and lysine. In: ADSA '97, Program and abstracts, $92^{\text {nd }}$ annual meeting, University of Guelph, June 22-25, 1997. Journal of Dairy Science 80, Supplement 1: 257.

Van Keulen, J. \& Young, B.A. 1977. Acid insoluble ash as a natural marker for digestibility studies. Journal of Animal Science 44: 282-287.

Varvikko, T., Vanhatalo, A., Huhtanen, P. \& Holma, M. 1996. Metioniinilisän vaikutus nurmisäilörehulla ruokitun lypsylehmän maidontuotantoon. Kotieläintieteen päivät 1996. Maaseutukeskusten Liiton julkaisuja 905: 147-150.

Wu, Z. \& Huber, J.T. 1994. Relationship between dietary fat supplementation and milk protein concentration in lactating cows: A review. Livestock Production Science 39: 141-155. 
Khalili, H. et al. Protein supplements for organic milk production

\title{
SELOSTUS
}

\section{Luonnonmukaisesti tuotetun valkuaisrehun vaikutus maidontuotantoon ja maidon koostumukseen}

\author{
Hannele Khalili, Eeva Kuusela, Eeva Saarisalo ja Marjatta Suvitie \\ Maatalouden tutkimuskeskus ja Joensuun yliopisto
}

Tutkimuksessa selvitettiin lypsylehmille annettavaan väkirehuun lisätyn valkuaisrehun vaikutuksia rehun syöntiin, maidontuotantoon, maidon koostumukseen ja ruokinnan sulavuuteen. Nurmi-apilasäilörehua annettiin vapaasti. Koeruokintoja oli kokeessa 1 neljä ja kokeessa 2 kolme. Molemmissa kokeissa lehmät saivat nurmi-apila säilörehua vapaasti ja väkirehua 8 kiloa päivässä. Kokeessa 1 kontrolliväkirehuna oli ohra-kauraseos (C). Kolmessa koeväkirehussa ohrakauraseosta oli korvattu joko luonnonmukaisesti tuotetuilla herneellä $(\mathrm{P})$, herneellä ja rypsillä (PRS) tai kaupallisella rypsirouheella (RSM). Kokeessa 2 kontrolliväkirehuna oli ohra-kaura-rypsipuristeseos (RSC). Kahdessa muussa koeväkirehussa kaupallisen rypsipuristeen sijasta käytetiin joko tilalla kylmäpuristettua luonnonmukaisesti viljeltyä rypsipuristetta (ORSC) tai kaupalliseen rypsipuristeruokintaan lisättiin rypsiöljyä (RSCO).

Kokeessa 1 kaikki valkuaislisäystä sisältänyttä ruokintaa lisäsivät hieman säilörehun syöntiä ja ener- giakorjattua maidontuotantoa (EKM). Herneruokinnoilla lehmät tuottivat lähes saman verran kuin rypsirouheruokinnoilla. Herne-rypsiseosta saaneet lehmät lypsivät eniten. RSM-ruokinnoilla valkuaispitoisuus oli korkein. Valkuaistuotoksessa ei ollut eroa valkuaislisäruokintojen välillä. Herne ja herne-rypsiseos olivat yhtä hyviä valkuaislisiä kuin rypsirouhe lehmien ollessa lypsykauden keskivaiheilla ja aminohappotaseen ollessa positiivinen.

Kokeessa 2 tilalla kylmäpuristetun luonnonmukaisen rypsipuristeen suurempi öljypitoisuus verrattuna kaupalliseen rypsipuristeeseen ei aiheuttanut haitallisia vaikutuksia. Kylmäpuristettua rypsipuristetta saaneiden lehmien EKM oli yhtä suuri kuin kaupallista rypsipuristetta saaneiden lehmien. Maidon koostumuksessa ei ollut myöskään eroa näiden kahden ruokinnan välillä. Rypsiöljyn lisääminen kaupalliseen rypsipuristeruokintaan vähensi säilörehun syöntiä, mutta lehmien EKM oli suurin tällä ruokinnalla. 